\title{
Entrepreneurship in the BRICS and cultural dimensions
}

\author{
Pedro Henrique Drummond Pecly ${ }^{1}$, Priscilla Cristina Cabral Ribeiro ${ }^{1}$
}

${ }^{1}$ Fluminense Federal University, Rio de Janeiro, RJ, Brazil.

How to cite: Pecly, P.H.D. and Ribeiro, P.C.C. (2020). Entrepreneurship in the BRICS and cultural dimensions. Brazilian Journal of Operations \& Production Management, Vol. 17, No. 2, e2020721.

https://doi.org/10.14488/BJOPM.2020.013

\section{ABSTRACT}

Goal: This article aims to identify the reasons that lead to the low expression of entrepreneurship in the BRICS through a literature review on cultural dimensions by the main authors.

Design / Methodology / Approach: The study was carried out through a bibliographic survey of the cultural dimensions in the cited authors, and of entrepreneurship in each one of the BRICS, in order to first define the cultural dimensions and values present in each nation and then explain the national entrepreneurial culture.

Results: The results reveal that the entrepreneurial attitude of a population is influenced by the cultural traits of the nation to which it belongs and by some economic aspects. Even though economic aspects influence the initiative to entrepreneur, they could be influenced by the main sector in the economy, by the nature of the entrepreneurship (opportunity or necessity), and by the dimensions of the authors under study.

Limitations of the investigation: The limitation of bibliographic research is the secondary source, which can produce contradictions.

Practical implications: The study shows to the nations (and their governments) what aspects of their cultures they must invest more time to motivate people to entrepreneur (culture dimensions). Governments can propose to industries present in the main sector and financial institutions to support research and entrepreneurship in the universities, in incubators and in technology parks. Some laws can be created to support entrepreneurial activities, and reduce the number of people who entrepreneur by necessity.

Originality / Value: The bibliometric study showed that there were not an article that united all five countries in a study about cultural dimensions and the low rate of entrepreneurship. This article contributes with this gap in the literature.

Keywords: Entrepreneurship; Entrepreneurial Culture; Cultural Dimensions; BRICS.

\section{INTRODUCTION}

As a group of emerging countries, the BRICS have some similarities in their economies. They have the common characteristic of late industrialization and a recent past as underdeveloped countries, though their monetary reserves, together, have a total of US\$ 100 billion. In 2018, one more annually meeting was done with them in South Africa, where these countries organized their political agenda and make effort together. They are cooperating intra group in more than 30 areas, such as health, science, technology and innovation, culture, and so on (Brasil, 2019).

According to Khan and Farooquie (2016), over the last 15 years, there has been a rapid growth of small and medium enterprises with certificates in the developing countries in general and India in particular, which lead us to understand that their economies are not

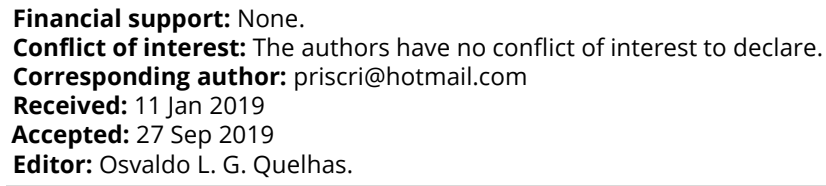

(c) (i) This is an Open Access article distributed under the terms of the Creative Commons Attribution License, which permits unrestricted use, c) distribution, and reproduction in any medium, provided the original work is properly cited. 
producing for their necessities, but to compete abroad, within developed countries. Based on this information, one could ask to what extent the entrepreneurial culture in these countries has contributed to this rapid growth through the action and presence of local ventures, and how this economic progress has favored and motivated the creation and consolidation of new ventures. As such, it is necessary to analyse the entrepreneurial culture of a nation to explain the involvement, creation and consolidation of ventures in the context of the BRICS, because despite their similar economic conjuncture, the cultural characteristic of each country may make their environment either favorable or unfavorable for entrepreneurship.

Taken together, these five countries cover $40 \%$ of the world population and more than 25 percent of the world's land. They delivered on some of that promise-from 1990 to 2014; these countries went from accounting for 11 percent of the world's GDP to almost 30 percent. Instead of their crisis, the group continues to meet and to talk up an ambitious common agenda (Bremmer, 2017).

These countries have "BRICS" as an acronym, which is associated with a change in global economic power, what means that the emerging economies are closing the gap with the developed nations, the members of the G-7. Ratten (2014, p. 266) says "many studies have been carried out in developed countries and few in developing or poor countries". Chevrier et al. (2014) state that the theories by Hofstede, Trompenaars and Hampden-Turner, and Schwartz are useful to compare differences on a general level, but inadequate to measure what occurs on the level of interpersonal relations.

McCarthy et al. (2010) state that there is a need to study the cultural similarities regarding the entrepreneurial characteristics that might provide support to the cultural convergence between the BRICS countries. Hofstede employed a neutral, global and scientific approach to study cultural dimensions of a nation (Thampi et al., 2015), but it would therefore be necessary to consider the context of the country, the micro-economic aspects and the specificities of the country.

In this context, the objective of this study is to identify the reasons that lead to the low expression of entrepreneurship in the BRICS through a review of the literature on cultural dimensions by Hofstede, Trompenaars and Hampden-Turner, Hall, Schwartz, and Kluckhohn and Strodtbeck. Despite the fact that there is some disagreement as to the term "emerging" and the classification of these countries (there is still no universal definition), this article will use the term to classify the countries and the economic block (BBC, 2015).

\section{ENTREPRENEURIAL CULTURE AND CULTURAL DIMENSIONS}

The entrepreneurial culture of a nation represents the rhythm of entrepreneurship and it can manifest itself in various ways, such as the entrepreneurial profile, collective entrepreneurship, entrepreneurial management, among other forms (Schmidt and Dreher, 2008). The existence and the combination of some of these forms and other manifestations are what constitute an entrepreneurial culture (Dreher, 2004). In turn, this culture plays an essential role in the profile of individuals, making them more or less prone to identify new business opportunities and the necessary means to capitalize on them, and in designing a structure that is better suited to take advantage of those identified opportunities (Stevenson and Gumpert, 1985).

It is therefore possible to analyse the cultural characteristics of a given region through cultural dimensions, which attempt to explain the various traits and behaviours of the population living in a certain location. Of the several existing models on cultural dimensions, this article will use five of the most well-known and cited authors until the present day. These are the models from Hofstede, Trompenaars and Hampden-Turner, Hall, Schwartz and Kluckhohn, and Strodtbeck. The application of several models is relevant because each focuses mostly on different cultural elements, contributing to a more comprehensive analysis of the cultures of the countries examined in this study (Nardon and Steers, 2009). 


\subsection{Hofstede's Cultural Dimensions}

Geert Hofstede carried out some research to develop a model of cultural dimensions that focused on "developing a commonly acceptable, well-defined and empirically sound terminology to describe cultures" and on "analysing the collected data in a systematic way and for a significant number of cultures, instead of using only impressions" (Lacerda, 2011, p. 1288). The cultural dimensions proposed by Hofstede are: power distance, resistance to uncertainty, individualism versus collectivism, masculinity versus femininity, Confucian versus dynamism.

Hayton et al. (2002) propose that when the level of entrepreneurship in a nation is associated with Hofstede's cultural dimensions, one can see that cultures characterized by a low power distance, a low resistance to uncertainty, individualism and masculinity have a greater tendency to opening up new businesses. This occurs because a high resistance to uncertainty and the predominance of a great power distance tend to generate barriers to innovation and entrepreneurship.

Shane (1993) and Lynn and Gelb (1996) argue that the individuality provides the necessary freedom so that projects can be carried out and the competition and the search for rewards generate the motivation that drives results to be as good as possible, what, according to the authors, justifies individualism and masculinity as ideal for the promotion of entrepreneurial activities. With respect to the notion of time, Hofstede et al. (2001) proposes that cultures with a long-term perspective are more responsive to changes and more flexible, which benefits innovative and entrepreneurial activity.

According to this discussion, the authors propose:

P1: Cultures characterized by a low power distance, a low resistance to uncertainty (to take risk), individualism and masculinity have a greater tendency to be an entrepreneur's nation.

\subsection{Trompenaars and Hampden-Turner's Cultural Dimensions}

For Fons Trompenaars and Charles Hampden-Turner, understanding a culture is possible if we keep in mind that the main element that differentiates individuals is the unique way that each one looks for solutions to solve problems (Trompenaars and Hampden-Turner, 1997). According to the authors, there are three classes of problems: those arising from relationships between people, those related to the passage of time, and those arising from the relationship with the environment (Lacerda, 2011). Based on these questions, Trompenaars and Hampden-Turner built seven cultural dimensions, such as universalism-particularism, individualism-communitarianism, specific-difuse, neutral-emotional, achievement-ascription, time perspective, and relationship with environment.

Lee and Peterson (2000) associated entrepreneurial attitude with the cultural dimensions of Trompenaars and Hampden-Turner and stated that it is strengthened by individualism, by the focus on achievement and reward as determining forms of motivation and by universalism, which are responsible for generating such traits as competitiveness, autonomy and a propensity to take risks in a society. According to these authors, the other dimensions did not contribute significantly to the development of the entrepreneurial attitude.

In this article, the second proposition is:

P2: Nations characterized by universalistic, individualism, focus on achievement, have reward as determining forms of motivation and by universalism in a society have a greater tendency to be an entrepreneur's nation

\subsection{Hall's Cultural Dimensions}

The model of cultural dimensions proposed by Edward T. Hall in 1959 was based on studies carried out in such countries as Germany, Japan, the United States and France. This model analysed interpersonal communication, the personal use of space, the perception of time and the speed with which messages are transmitted in the societies of each of the countries under study (Hall and Hall, 1990). The cultural dimensions of this model are context, space and time. 
According to Steers and Nardon (2005), more entrepreneurial countries are marked by low context, a territorial concept of space and a monochronic approach to time, which suggests that cultures that are closer to these dimensions tend to be more enterprising than the others. Van Everdingen and Waarts (2003) argue that due to the fact that decisions related to the development of entrepreneurial activities are taken often in a rational manner, based on comprehensive and reliable information using a wide variety of sources, low context cultures are considered beneficial for the performance of entrepreneurial activity.

This discussion lead to a third proposition:

P3: Nations characterized by a low context, a territorial concept of space and a monochronic approach to time could be potential entrepreneur's countries.

\subsection{Schwartz' Cultural Dimensions}

Shalom Schwartz identified the universal human values present in all cultures and which represent the universal needs of human existence through an approach that focused on the inherent elements of the psychology of social values that permeate a culture (Nardon and Steers, 2009). Based on these universal values, Schwartz built his model of these cultural dimensions: embeddedness-autonomy, hierarchy-egalitarianism, mastery-harmony (Schwartz, 2012).

As suggested by Godói-de-Sousa et al. (2014), and when adapting the arguments put forth by Lee and Peterson (2000) and Hayton et al. (2002) to Schwartz' dimensions, one can see that some factors, which foster entrepreneurship in a society are individualism, characterized by the autonomy of individuals to act and think, and a low power distance, which exists in egalitarian societies. When the Mastery-Harmony scale is concerned, both can collaborate to foster entrepreneurship, but while one drives the quest for innovation, the other encourages the use of already known ideas.

The fourth proposition, considering these authors is:

P4: Nations characterized by the autonomy of individuals to act and think, a low power distance, which exists in egalitarian societies, and Mastery-Harmony values have a chance to be entrepreneur's nation.

\subsection{Kluckhohn and Strodtbeck's Cultural Dimensions}

Based on the assumption that all cultures are subject and have to deal with a common set of problems, Kluckhohn and Strodtbeck (1961) carried out field research to compare the guiding principles of individuals from different cultures. Through this study, the two scholars arrived at their own model of cultural dimensions, presenting some of them: Relationship with Nature, Relationship with People, Human Activities, Relationship with Time, Human Nature.

Thomas and Peterson (2014) suggest that the ideal set of scales to consolidate a strong entrepreneurial attitude in a nation, among the dimensions proposed in the model discussed in this item, consists in the association of mastery over nature with individualistic relations with other individuals, and as also proposed by Shane (1993) and Lynn and Gelb (1996), a belief in "doing", a focus on the present time and a belief in the neutral nature of the human being.

The fifth proposition is:

P5: The nations which are characterized by association of mastery over nature with individualistic relations with other individuals, a belief in "doing", a focus on the present time and a belief in the neutral nature of the human being.

Table 1 summarizes the cultural dimensions that lead to an entrepreneur behaviour in a nation. 
Table 1. Ideal dimensions for entrepreneurship

\begin{tabular}{|c|c|}
\hline Authors & Stimulating Aspects of Entrepreneurship \\
\hline \multirow{4}{*}{ Hofstede } & Low power distance \\
\hline & Low resistance to uncertainty \\
\hline & Individualism \\
\hline & Masculinity \\
\hline \multirow{3}{*}{ Trompenaars and Hampden-Turner } & Universalism \\
\hline & Individualism \\
\hline & Focus on achievement \\
\hline \multirow{3}{*}{ Hall } & Low context \\
\hline & Territorial \\
\hline & Monochronic approach to time \\
\hline \multirow{3}{*}{ Schwartz } & Autonomy \\
\hline & Egalitarianism \\
\hline & Mastery-Harmony \\
\hline \multirow{5}{*}{ Kluckhohn and Strodtbeck } & Mastery \\
\hline & Individualism \\
\hline & Doing \\
\hline & Present \\
\hline & Neutral \\
\hline
\end{tabular}

Source: The authors themselves

\section{METHODOLOGY}

As for the type of research, a bibliographic and document study was employed. The theoretical information concerning the cultural dimension models to be explored was gathered. In addition, the authors and publications that addressed the concept of entrepreneurial culture, the characteristic cultural traits of countries that make up the BRICS and the reality of entrepreneurial activity in the nations in question, were researched.

Because in this article the goal is to answer the question "What are the reasons that lead BRICS to a low expression of entrepreneurship?", the bibliographic research is a part of an experimental research, because the authors aimed to understand why these countries (through their entrepreneurship cultures) have a low expression of their entrepreneurship. In addition, as Oliveira (2007, p. 69) assumed, this article uses a documental research because the authors used data from sources, which are not books, journals, essays, dictionaries, and scientific papers, what means that they did not receive any scientific treatment, as reports and magazines. The limitations of documental research are its subjectivity and, sometimes, the documents are not representative. Here, in this paper, the authors chose reports (Brasil, 2019; Global Entrepreneurship Monitor, 2018; International Monetary Fund, 2013), which have different countries joining a research about entrepreneurship and a sort of data about their performance in this activity. These sources present different data, and they were used for this purpose, to confirm and show statistics and economic data. This characteristic of these sources show that they are very objective, meaning that in this paper, the documental research does not present any limitation. The limitation of bibliographic research is the secondary source, which can produce contradictions.

In order to get a more complete picture, such databases as Scopus and Web of knowledge were used, especially in the survey phase of articles that could help justify the study and the analysis of the authors to find the ideal conditions for entrepreneurship. The keywords were defined as entrepreneur, entrepreneurship, culture, the country, and related words, according to the search, keeping in mind that different keywords emerged for each country, with the exception of those mentioned above, which were common to the results. The operator used was 'AND', searching only for articles, words in the title, abstract or keywords, with a focus on 
the field of Business, Economics, Multidisciplinary, Social Science, and Decision Science. As the affinities between the BRICS are also economic in nature, studies by the IMF and Brazilian government studies were also used.

Both the Global Entrepreneurship Index (GEI) (Ács et al., 2018) and Global Entrepreneurship Monitor (2018) are reports on global studies on various countries, around a same or more variables, which allows for a joint or separate analysis of entrepreneurship. The analyses and studies on the entrepreneurial activity of countries are often imprecise and subjective. The creation of the GEM, however, has made it easier to access accurate and current data on entrepreneurship in various nations (Fontenele et al., 2011). With respect to the analysis of the entrepreneurial performance of the countries, GEl has the advantage of merging several important factors for the evaluation of a nation's entrepreneurship into a single factor, providing a score for each country based on Entrepreneurial Performance, though it has similarities with the GEM.

Table 2 provides information on the BRICS countries to help characterize the sample. One can see that the countries have similarities regarding their position on the GEI and innovation index, and some differences in the ranking of entrepreneurial countries and the characteristics of entrepreneurship. These similarities occur because of common past policy experiences in some countries. In addition, it can be justified by the performance of sectors, such as the primary sector, in all of them, due to the agricultural vocation of some them and because of the low past public and private investments in innovation and science and technology policies. The Table 2 will show the rank in 54 countries in GEM database according to gender, and the kind of entrepreneurship is more common in each country, necessity or opportunity. Russia does not appear in GEM, it is possible that the country did not participate in this research.

Table 2. Entrepreneurship in the BRICS

\begin{tabular}{|c|c|c|c|c|c|c|}
\hline \multirow[b]{2}{*}{ Countries } & \multirow[b]{2}{*}{ GEI Score in 2018} & \multirow{2}{*}{$\begin{array}{l}\text { The ranking of } \\
\text { entrepreneurial } \\
\text { countries }\end{array}$} & \multicolumn{4}{|c|}{ Opportunity (O) or necessity (N) } \\
\hline & & & $\begin{array}{c}\text { Male } \\
(0)\end{array}$ & $\begin{array}{c}\text { Female } \\
\text { (0) }\end{array}$ & $\begin{array}{c}\text { Male } \\
(\mathrm{N})\end{array}$ & $\begin{array}{c}\text { Female } \\
(\mathrm{N})\end{array}$ \\
\hline Brazil & 20.3 & 98th. & 50 & 48 & 5 & 5 \\
\hline Russia & 25.2 & 78th. & - & - & - & - \\
\hline India & 20.4 & 68th. & 54 & 54 & 3 & 7 \\
\hline China & 41.1 & $43 r d$. & 51 & 34 & 4 & 19 \\
\hline South Africa & 32.9 & 57th. & 13 & 37 & 31 & 14 \\
\hline
\end{tabular}

Source: Designed from Ács et al. (2018) and Global Entrepreneurship Monitor (2018)

\section{ANALYSIS OF THE ENTREPRENEURSHIP IN BRICS}

\subsection{General aspects of BRICS countries (political, geographic and local, economic, cultural, ethical, and educational)}

The characteristics presented by the BRICS suggest that entrepreneurial activities differ from country to country, which leads to the challenge of analysing their cultural dimensions. However, these countries have their similarities and differences, which support their level of entrepreneurship, and are showed below.

According to Ardichvili et al. (2012), the term BRICS was coined by analysts at Goldman Sachs. While the G7 is the body that brings together the big rich economies, BRICS brings together the big emerging powers and markets, whose economic growth is predicted to outstrip and indeed anchor the rest of the world. These countries have a lot of diversity and spread of continents, political systems and values, separate histories, contexts, political systems, needs, opportunities and futures economic models that they span (Thakur, 2014). To discuss the differences and similarities among them, some aspects were analyzed as political, geographic, economic, cultural, and ethical. 
The political aspects are considered, because two of these countries are authoritarian states, and the other three are democracies, although they too have a tradition of reticence of global democracy promotion efforts (Thakur, 2014, p. 1793). Because of the prevalence of different legal and cultural traditions in various countries, they do not have an enforcement on the ground of public policy. Hence, until a harmonized approach to public policy toward foreign awards is developed at an international level, the BRICS countries may take initiative to set up an inter-regional arbitration council to resolve intricate cases occurring in the field of application of public policy exception to foreign arbitral awards (Bansal and Aggarwal, 2017).

BRICS countries have significant similarities in terms of geographic size, market size and huge population (Hasan, 2016). Globalisation is catalised by funds of investments, but its major trends have different faces depending on countries, geographical and economic stand point. In these countries, different benefits from nature and human resources lead them to different economic results.

On one hand these economies are not as part of some uniform entity (and compete among them), on the other hand they have some issues with some common interests, and will even collaborate with some Western and industrialized powers (Ardichvili et al., 2012; Thakur, 2014). India and China are most powerful in this group, though India has some constrains, because its importations exceeds its exportations (as Brazil) (Thakur, 2014). They have problems among them, related to their external trading, as China and Brazil (about imports tariffs) (Pearson and Leahy, 2011), and China and South Africa, where Chinese government buys raw materials contributing to the African deindustrialization and underdevelopment, followed by cheap Chinese manufactured products flooding South Africa (Chima, 2013). India is a big emerging market, with common interests shared with developed countries. In the BRICS three countries (Brazil, China, and Russia) have shown the biggest progress towards poverty eradication. Brazil and China are regional leaders in poverty eradication relative to the international extreme poverty threshold within the strategy of achieving the Millennium Development Goals, namely to "halve the proportion of people whose income is less than 1 dollar a day" (Massarova and Potapenko, 2018).

The rich culture of India, immersed in spirituality and religion, is focused on intuitive ethical decision making, which sets it apart from the Western analytical approach to ethical decision making based on norms. Factors, such as culture, education, and gender, play a significant role in shaping moral perspectives and ethical values. The Brazilian business culture is as diverse as the larger sociocultural environment of this dynamic country. Such elements as loyalty and flexibility, personal relationships, and "jeitinho" exist side-by-side with Western cultural components, manifested in the use of codes of ethics and formal ethics programs (Ardichvili et al., 2012). This means that the BRICS countries are challenged to develop their own approaches from their own cultural perspectives (Faust et al., 2018).

The ethical culture aspects present significant differences among BRIC countries. Russia and China have some similarities in these aspects, both cultures are paternalistic with a high importance placed on loyalty. Maybe because they share a recent legacy of communist economies and political arrangements, which could have shaped the trajectory of development of business cultures in general and ethical business cultures in particular (Ardichvili et al., 2012).

Related to the discussion above, some authors as Lund-Thomsen and Wad (2014) consider India, Brazil and South Africa a group inside BRICS countries, naming them IBSA countries. These countries share a number of common characteristics that make the study of global value chains, local economic organization and Corporate Social Responsibility in these contexts particularly interesting, such as political, all of them are liberal democracies. They formed IBSA in 2003 to advance their claim to a higher international political status and UN Security Council seats that were otherwise occupied by Russia and China. In addition, whereas they differ in terms of their population size, availability of natural resources, income patterns and cultural diversity, India, Brazil and South Africa share many similar socio-economic challenges, as we saw above.

These characteristics (political, geographic, economic, ethical, and cultural) have been lead the group (BRICS) to educational models and innovation. In the 2018, The Asia-Pacific 
region on average scores best (and is improving) in Product Innovation. The region is also strong in Human Capital. South / Central America and the Caribbean is strongest in the areas of Startup Skills and Product Innovation. The Asia-Pacific region shows greatest strength in Human Capital and Product Innovation - on average, countries in the Asia-Pacific region have highly educated populations that are well trained in business and able to move freely in the labor market. They are also producing products that are new to customers and integrating new technology (Ács et al., 2018).

The South/Central America and the Caribbean region scores highest on average on Startup Skills and Product Innovation. Entrepreneurs benefit from broadly available tertiary education and a high levels of business skill. They are also creating products that are new to markets and integrating new technology into their businesses. Unlike regions with more balanced performance, this region has an opportunity to create significant improvements by focusing on a small number of key bottlenecks: Process Innovation and Risk Capital. Similar to previous years, Chile far outperforms the rest of the region, with a score forty percent higher than the region's second highest score. The conclusion is that certain aspects of being an entrepreneur have become a bit harder, but entrepreneurs are more than meeting this challenge with new skill acquisition and improvements in innovation capacity (Ács et al., 2018). According to this report, China and Brazil are in regions where the level of innovation increased more than in South Africa, India and Russia.

The level of innovation comes from the model of education, and the entrepreneurial motivation is created by an investment from elementary school to university level (or tertiary). Using a sample of 9,753 students, Gonzalez et al. (2019) concluded that the influence of the university environment is the antecedent with the greatest effect on entrepreneurial intention; therefore, it is recommended that entrepreneurship be promoted through initiatives and educational programmes in the university environment. The idea of study entrepreneurship at universities became from Etzkowitz triple helix structure (see Leydesdorff and Etzkowitz, 1996), where universities were the place to study entrepreneurship to motivate students to be an entrepreneur. Educators and policymakers are increasingly interested in making entrepreneurship education accessible to engineering and other majors students to innovation and the economy, which can lead the countries to a practical result, the country to increase its economic development (Cao and Zhou, 2018; Yi and Duval-Couetil, 2018).

After discuss some aspects of these countries, based on the cultural dimensions of the authors used in this article (Hofstede, Trompenaars and Hampden-Turner, Hall, Schwartz, and Kluckhohn and Strodtbeck), and on the literature available on this subject that was addressed here, the most suitable dimensions for each one of the BRICS can be defined through the characteristic cultural traits of these countries, as show below.

\subsection{Analysis of entrepreneurial cultures in BRICS}

\subsubsection{Based on Hofstede's cultural dimensions}

In Brazil, the great discrepancy in the distribution of power in the population leads to the benefits of the individual being proportionate to the power he holds. When resistance to uncertainty is concerned, Brazil has a similar behaviour to the majority of Latin American countries, with a high degree of aversion to ambiguous situations. With respect to the individualism and collectivism dimension, people in the country tend to be integrated into the groups by strong personal ties since birth, especially family ties, in which members protect each other in exchange for loyalty. One can see that the society finds itself in an intermediate position on the masculinity/femininity scale due to strong control relationships resulting from established hierarchies that, as a counterpart, are balanced by the harmony, which tends to be found in the relationship of groups of individuals (Hofstede, 2015a). Regarding time, Brazilian culture is geared to the long term, which justified by the desire for a more equal and fairer future for the population.

In Russia, the distribution of power in society is very unequal. As for the aversion to uncertainty, the Russians tend to feel threatened by ambiguous situations. To avoid them, Russians appear to have the custom of planning actions in detail, while at the same time they 
seem to have the most complex bureaucracies in the world (Hofstede, 2015b). This fact does not prevent Russian society from being prepared to adapt their traditions to new trends for a prosperous future, however. Although the search for success and status is of high importance to the Russians, they consider family, friends, and even neighbours to be important in the day-to-day challenges. They therefore tend to stick to and strengthen the groups to which they belong (collectivism) (Hofstede, 2015b).

Indian society has an appreciation for hierarchy, often because of the cast society that characterizes the country (Hofstede, 2015c). The author highlights that communication occurs from top to bottom and that power is highly centralized. The aversion to uncertainty is low in its inhabitants, since the country is marked by the acceptance to imperfection and the imposed rules are circumvented through creative solutions to sidestep problems. Some of the principles of Hinduism, the predominant religion in the country, intensify the quest for individual success even further, as it preaches a cycle of death and rebirth that is dependent on how the individual lived his prior life (Hofstede, 2015c). The author also emphasizes that, in terms of success and power, the country is very masculine. As a counterpoint to this phenomenon, Indians put a high value on family, which makes them reconcile their individual achievements with those that will lead to benefits to the group as a whole. However, as a result of the concept of "Karma", Indians premeditate many actions, fearing the impacts that their acts may cause. As such, they do not value time the same way Western societies do.

Abuse of power is frequent in Chinese society because it easily accepts inequalities between people. The relationship between subordinates and superiors is polarized (Hofstede, 2015d). Regarding the aversion to uncertainty, the same author suggests that the Chinese have a higher tolerance for ambiguous situations. He also states that Chinese culture is highly collectivistic, because the issues relating to the common good are considered more important than the individual success of the members of society. Despite this, individual success is still very important in society and it is one of the main drivers of individuals, indicating a masculine character of this culture. An adaptation of traditions to new conditions can be observed, demonstrating that culture is in constant change toward the future (Hofstede, 2015d).

In South Africa, the situation is more complex than in the other countries under study because of the effects of Apartheid, which contributes to the country having a divided culture: with an Afrocentric part on one hand, and an Eurocentric part on the other (De Beer, 1997). The Afrocentric culture is characterized by an acceptance of inequalities, collectivistic individuals, a feminine culture and a greater focus on the present. The Eurocentric culture also accepts inequalities, but, unlike their counterparts, this leads to an individualistic character in the population, whose objective consists in growth and personal success, demonstrating the masculine character of this culture. Individuals act in the present with a focus on a more prosperous future (Smit et al., 2004). The authors also emphasize that, in addition, the population has a low aversion to ambiguous situations. Table 3 shows the relationship between the dimensions and the countries:

Table 3. Hofstede's cultural dimensions applied to the BRICS

\begin{tabular}{|c|c|c|c|c|c|c|}
\hline $\begin{array}{c}\text { Dimension/ } \\
\text { Country }\end{array}$ & Brazil & Russia & India & China & $\begin{array}{l}\text { South Africa } \\
\text { (Afrocentric) }\end{array}$ & $\begin{array}{c}\text { South Africa } \\
\text { (Eurocentric) }\end{array}$ \\
\hline $\begin{array}{c}\text { Power } \\
\text { Distance }\end{array}$ & High & High & High & High & High & High \\
\hline $\begin{array}{c}\text { Resistance to } \\
\text { Uncertainty }\end{array}$ & High & High & Low & Low & High & Low \\
\hline $\begin{array}{l}\text { Individualism } \\
\text { and } \\
\text { Collectivism }\end{array}$ & Collectivism & Collectivism & Collectivism & Collectivism & Collectivism & Individualism \\
\hline $\begin{array}{l}\text { Masculinity } \\
\text { and } \\
\text { Femininity }\end{array}$ & $\begin{array}{c}\text { Intermediat } \\
\mathrm{e}\end{array}$ & Femininity & Masculinity & Masculinity & Femininity & Masculinitye \\
\hline $\begin{array}{l}\text { Confucian } \\
\text { Dynamism }\end{array}$ & $\begin{array}{l}\text { Focus on the } \\
\text { long term }\end{array}$ & $\begin{array}{l}\text { Focus on the } \\
\text { long term }\end{array}$ & $\begin{array}{l}\text { Focus on the } \\
\text { short term }\end{array}$ & $\begin{array}{l}\text { Focus on the } \\
\text { long term }\end{array}$ & $\begin{array}{l}\text { Focus on the } \\
\text { short term }\end{array}$ & $\begin{array}{l}\text { Focus on the } \\
\text { long term }\end{array}$ \\
\hline
\end{tabular}

Source: Designed from De Beer (1997) and Hofstede (2015a; 2015b; 2015c; 2015d) 
According to Tables 2 and 3, China and Eurocentric part of South Africa are better positioned in the ranking of entrepreneurial countries, what means that proposition 1 is confirmed, based on Hofstede's theory, because both of them have a low Resistance to Uncertainty/risk.

\subsubsection{Based on Trompenaars and Hampden-Turner's cultural dimensions}

There are other characteristics of Brazilian culture that should be explained, such as the ease with which some general rules are applied in distinct ways, even if illegally, making personal relationships and the particularities of each situation change existing standards. The option for individuals to express their feelings in public, the frequent union of professional and personal relationship in the work environment, and, finally, the lack of control of the environment and nature turns the country a place where the results of entrepreneurship are not impressive (Trompenaars and Hampden-Turner, 1997).

In Russia there's a focus on particularism (despite the existence of strict rules and standards), on the display of affection in public places, on the mixing of personal and professional relationships in varied situations, and on not trying to control nature and the environment. In addition, Russian culture is marked by ascription, where the financial condition and family of origin of an individual are factors that are of great influence in relations (Gilbert, 2001).

Indian culture relies heavily on ascription as a result of the country's cast system. Personal and professional relationships are confused in daily life, rules and standards can be changed, and Indians only observe nature; they do not try to control it. The definition of culture is between emotional and neutral, because the behaviour of Indians falls between the two extremes (Overgaard, 2010).

In China there is equality in the compliance with rules, repression of feelings and emotions in public places, a greater importance of ascription than of achievement, a separation between personal and professional relationships at work places, and, finally, a submission to nature (Chan, 1999).

According to De Beer (1997), in South Africa individuals are particularistic, i.e., standards and rules are particular and are focused on well-being, i.e. this culture is characterized as feminine. People do therefore express their feelings in public places and blend personal and professional relationships in various situations. In addition, the status of an individual is judged by his achievements and they do not try to control the environment and nature, being only guided by them.

In Table 4, the cultural dimensions of Trompenaars and Hampden-Turner are listed and applied to the BRICS.

Table 4. Cultural dimensions of Trompenaars and Hampden-Turner applied to the BRICS

\begin{tabular}{|c|c|c|c|c|c|c|}
\hline $\begin{array}{l}\text { Dimension/ } \\
\text { Country }\end{array}$ & Brazil & Russia & India & China & $\begin{array}{l}\text { South Africa } \\
\text { (Afrocentric) }\end{array}$ & $\begin{array}{l}\text { South Africa } \\
\text { (Eurocentric) }\end{array}$ \\
\hline $\begin{array}{l}\text { Universalism- } \\
\text { Particularism }\end{array}$ & Particularism & Particularism & Particularism & Universalism & Particularism & Universalism \\
\hline $\begin{array}{l}\text { Individualism- } \\
\text { Communitari } \\
\text { anism }\end{array}$ & $\begin{array}{l}\text { Communitari } \\
\text { anism }\end{array}$ & $\begin{array}{l}\text { Communitari } \\
\text { anism }\end{array}$ & $\begin{array}{l}\text { Communitari } \\
\text { anism }\end{array}$ & $\begin{array}{l}\text { Communitari } \\
\text { anism }\end{array}$ & $\begin{array}{l}\text { Communitari } \\
\text { anism }\end{array}$ & Individualism \\
\hline $\begin{array}{l}\text { Specific- } \\
\text { Diffuse }\end{array}$ & Diffuse & Diffuse & Diffuse & Specific & Diffuse & Specific \\
\hline $\begin{array}{l}\text { Neutral- } \\
\text { Emotional }\end{array}$ & Emotional & Emotional & Intermediate & Neutral & Emotional & Neutral \\
\hline $\begin{array}{l}\text { Achievement- } \\
\text { Ascription }\end{array}$ & Ascription & Ascription & Ascription & Ascription & Achievement & Ascription \\
\hline $\begin{array}{c}\text { Time } \\
\text { Perspective }\end{array}$ & $\begin{array}{l}\text { Focus on the } \\
\text { future }\end{array}$ & $\begin{array}{l}\text { Focus on the } \\
\text { future }\end{array}$ & $\begin{array}{l}\text { Focus on the } \\
\text { past/present }\end{array}$ & $\begin{array}{l}\text { Focus on the } \\
\text { future }\end{array}$ & $\begin{array}{l}\text { Focus on the } \\
\text { past/present }\end{array}$ & $\begin{array}{l}\text { Focus on the } \\
\text { future }\end{array}$ \\
\hline $\begin{array}{l}\text { Relationship } \\
\text { with the } \\
\text { environment }\end{array}$ & $\begin{array}{l}\text { External } \\
\text { direction }\end{array}$ & $\begin{array}{l}\text { External } \\
\text { direction }\end{array}$ & $\begin{array}{l}\text { External } \\
\text { direction }\end{array}$ & $\begin{array}{l}\text { External } \\
\text { direction }\end{array}$ & $\begin{array}{l}\text { External } \\
\text { direction }\end{array}$ & $\begin{array}{l}\text { External } \\
\text { direction }\end{array}$ \\
\hline
\end{tabular}

Source: Designed from De Beer (1997), Chan (1999), Gilbert (2001), Overgaard (2010), and Trompenaars and Hampden-Turner (1997) 
According to the text above, and Tables 4 and 2, Proposition 2 is not totally confirmed, because China is best positioned than South Africa. This last country presents one more characteristic (individualistic) to be an entrepreneur nation, comparing to China. According to Trompenaars and Hampden-Turner (1997) none of these nations based their culture in the dimension achievement, but both of them have reward as determining forms of motivation and by universalism, showing a greater tendency to be an entrepreneur's nation.

\subsubsection{Based on Hall's cultural dimensions}

While the Brazilian, Russian and Indian cultures are characterized by a high context in their communications, by the communal notion of space and by the polychronic approach to time (Fernandes, 2008; Steers and Nardon, 2005; Gelfand and Brett, 2004; Lewis, 1999; Nishimura et al., 2008), showing an appreciation of the community and the collective space associated with a communication marked by several non-verbal elements and a simultaneous approach and execution to the various daily activities and tasks. Chinese culture is characterized by a high context in their communications, by a territorial concept of space and by a monochronic approach to time, which differs from the previous countries in terms of the execution of day-today activities, being performed in a more focused and directed way in this case (Fernandes, 2008). Afrocentric South Africa is characterized by high context, by a communal notion of space and by a monochronic approach to time, whereas the Eurocentric culture is marked by low context, by a territorial concept of space and a monochromic approach to time, indicating a considerable difference between the two parts of this country (lacob and Dumitrescu, 2012). Table 5 shows the relationship between Hall's cultural dimensions and the BRICS.

Table 5. Hall's cultural dimensions applied to the BRICS

\begin{tabular}{ccccccc}
\hline $\begin{array}{c}\text { Dimension/ } \\
\text { Country }\end{array}$ & Brazil & Russia & India & China & $\begin{array}{c}\text { South Africa } \\
\text { (Afrocentric) }\end{array}$ & $\begin{array}{c}\text { South Africa } \\
\text { (Eurocentric) }\end{array}$ \\
\hline Context & High-Context & High-Context & High-Context & High-Context & High-Context & Low-Context \\
\hline Space & Communal & Communal & Communal & Territorial & Communal & Territorial \\
\hline Time & Polychronic & Polychronic & Polychronic & Monochronic & Polychronic & Monochronic \\
\hline
\end{tabular}

Source: Designed from Fernandes (2008), Gelfand and Brett (2004), lacob and Dumitrescu (2012), Lewis (1999),

Nishimura et al. (2008) and Steers and Nardon (2005)

Based on Tables 5 and 2, China and South Africa (Eurocentric) have best positions in the ranking, but South Africa has more common points than China, though this last country is in a higher position than South Africa. Then, the position in GEl and the Hall's dimensions do not conciliate at all, making the proposition 3 not confirmed at all.

\subsubsection{Based on Schwartz' cultural dimensions}

The analysis of Table 6 reveals that the five countries analysed are characterized by embeddedness, applying Schwartz' cultural dimensions to the BRICS by hierarchical structures and by being based on harmony.

Table 6. Schwartz' cultural dimensions applied to the BRICS

\begin{tabular}{|c|c|c|c|c|c|c|}
\hline $\begin{array}{l}\text { Dimension/ } \\
\text { Country }\end{array}$ & Brazil & Russia & India & China & $\begin{array}{l}\text { South Africa } \\
\text { (Afrocentric) }\end{array}$ & $\begin{array}{l}\text { South Africa } \\
\text { (Eurocentric) }\end{array}$ \\
\hline $\begin{array}{l}\text { Embeddedness } \\
\text { - Autonomy }\end{array}$ & Embeddedness & Embeddedness & Embeddedness & Embeddedness & Embeddedness & Autonomy \\
\hline $\begin{array}{c}\text { Hierarchy - } \\
\text { Egalitarianism }\end{array}$ & Hierarchy & Hierarchy & Hierarchy & Hierarchy & Hierarchy & Hierarchy \\
\hline $\begin{array}{l}\text { Mastery - } \\
\text { Harmony }\end{array}$ & Harmony & Harmony & Harmony & Harmony & Harmony & Harmony \\
\hline
\end{tabular}

Source: Designed from De Beer (1997) and Nardon and Steers (2009) 
The analysis above makes sense when checking the Table 6 and comparing the idea behind these dimensions to the ones with a considerable similar content analysed on the previous models, such as power distance, individualism-collectivism, individualism-communitarianism. The exception is Eurocentric South African culture that presents "autonomy" as a prevailing cultural trait instead of embeddedness, which, according to Smit et al. (2004) is related to the individualistic behaviours and relations present in that society.

According to proposition 4, nations characterized by the autonomy of individuals, egalitarianism and Mastery-Harmony scale have a chance to be entrepreneur's nation. On the one hand, based on this affirmation, South Africa Eurocentric has one more dimension than China, which led to conclude that this country has more chance to be an entrepreneur for authors. On the other hand, based on GEI Index, China is in a higher position than South Africa. Because the analysis is support by both sources, proposition 4 cannot be confirmed at all.

\subsubsection{Based on Kluckhohn and Strodtbeck's cultural dimensions}

When analyzing the culture of the BRICS based on the application of the cultural dimensions of Kluckhohn and Strodtbeck, as presented in Table 7, one can see that the countries in question have a harmonious relationship with nature, without submitting or trying to dominate it. With respect to the "Relationship with People", it is possible to observe that, with the exception of Eurocentric South Africa, the remaining countries accept and understand that they live in a society marked by inequality and by the hierarchy in relations (Ahlstrom and Bruton, 2009; Bertsch and Ondracek, 2010). The dimensions "Human activity" and "Relationship with Time" are linked because cultures that look to the future (the cases of Brazil, Russia, China and Eurocentric South Africa) believe that the only way they can develop and improve is by "doing", while the cultures focused on the past or present (India and Afrocentric South Africa) tend to value "being", since the history and traditions of a people, which are highly regarded in this type of society, define its individuals, which is sufficient for them in and by itself (Chan and Rossiter, 1998; Chatterjee and Heuer, 2006; Heuer, 2006; Grachev and Bobina, 2006). Finally, the authors also argue that the individuals of the countries analysed here tend to understand that human nature is neutral. Human beings are neither inherently good nor bad. Table 7 shows Kluckhohn and Strodtbeck's cultural dimensions applied to the BRICS.

Table 7. Kluckhohn and Strodtbeck's cultural dimensions applied to the BRICS

\begin{tabular}{ccccccc}
\hline $\begin{array}{c}\text { Dimension/ } \\
\text { Country }\end{array}$ & Brazil & Russia & India & China & $\begin{array}{c}\text { South Africa } \\
\text { (Afrocentric) }\end{array}$ & $\begin{array}{c}\text { South Africa } \\
\text { (Eurocentric) }\end{array}$ \\
\hline $\begin{array}{c}\text { Relationship } \\
\text { with Nature }\end{array}$ & Harmony & Harmony & Harmony & Harmony & Harmony & Harmony \\
\hline $\begin{array}{c}\text { Relationship } \\
\text { with People }\end{array}$ & Linear & Linear & Linear & Linear & Linear & Individualistic \\
\hline $\begin{array}{c}\text { Human } \\
\text { Activities } \\
\begin{array}{c}\text { Relationship } \\
\text { with Time }\end{array}\end{array}$ & Doing & Doing & Being & Doing & Being & Doing \\
\hline Human Nature & Neutral & Neutral & Neutral & Neutral & Neutral & Future \\
\hline
\end{tabular}

Source: Designed from Ahlstrom and Bruton (2009), Bertsch and Ondracek (2010), Chan and Rossiter (1998), Chatterjee and Heuer (2006), Heuer (2006) and Grachev and Bobina (2006)

In Table 8, which is the application of Table 1, one can see that, of the 18 aspects gathered from the theories of the authors, Eurocentric South Africa only has different characteristics regarding the concept of entrepreneurship in four of these aspects. 
Table 8. Ideal dimensions for entrepreneurship applied to the best positioned countries in BRICS

\begin{tabular}{|c|c|c|}
\hline Authors & $\begin{array}{l}\text { Stimulating Aspects of } \\
\text { Entrepreneurship }\end{array}$ & South Africa (Eurocentric) \\
\hline \multirow{4}{*}{ Hofstede } & Low power distance & High \\
\hline & Low resistance to uncertainty & Low \\
\hline & Individualism & Individualistic \\
\hline & Masculinity & Masculine \\
\hline \multirow{3}{*}{$\begin{array}{c}\text { Trompenaars and Hampden- } \\
\text { Turner }\end{array}$} & Universalism & Universalist \\
\hline & Individualism & Individualistic \\
\hline & Focus on achievement & Focus on achievement \\
\hline \multirow{3}{*}{ Hall } & Low context & Low context \\
\hline & Territorial & Territorial \\
\hline & Monochronic approach to time & Monochronic approach to time \\
\hline \multirow{3}{*}{ Schwartz } & Autonomy & Autonomy \\
\hline & Egalitarianism & Hierarchy \\
\hline & Mastery-Harmony & Mastery-Harmony \\
\hline \multirow{5}{*}{ Kluckhohn and Strodtbeck } & Mastery & Harmony \\
\hline & Individualistic & Individualistic \\
\hline & Doing & Doing \\
\hline & Present & Future \\
\hline & Neutral & Neutral \\
\hline
\end{tabular}

Source: The authors themselves

The results of the GEI 2015 and GEI 2018, in which South Africa and China obtained the best result among the BRICS reveal how the attitude of other countries in BRICS group regarding entrepreneurial activity is still weak, indicating an entrepreneurial culture of low expression in these locations. This Table is very helpful to confirm or not the proposition 5. Except for the dimensions doing and neutral, the other dimensions from Kluckhohn and Strodtbeck do not align with the issue from Ács et al. (2018), defining a nation as an entrepreneur, because China and South Africa (Eurocentric) do not have these dimensions in their culture.

Finally, Table 9 shows the common dimensions of the BRICS countries for each author. In this Table, the countries have the " " dimensions in common, namely: high power distance (Hofstede), relationship with the environment/external direction (Trompenaars and HampdenTurner), Hierarchy-Egalitarianism (hierarchy) and Mastery-Harmony (harmony) (Schartwz), and Relationship with Nature (harmony) and Human Nature (neutral) (Kluckhohn and Strodtbeck).

Table 9. Dimensions in common of the countries

\begin{tabular}{|c|c|c|c|c|c|c|c|}
\hline \multicolumn{2}{|c|}{ Dimensions/Countries } & \multirow{2}{*}{$\begin{array}{c}\text { Brazil } \\
\qquad \bullet\end{array}$} & \multirow{2}{*}{$\begin{array}{c}\text { Russia } \\
\end{array}$} & \multirow{2}{*}{$\frac{\text { India }}{\bullet}$} & \multirow{2}{*}{$\begin{array}{c}\text { China } \\
\end{array}$} & \multirow{2}{*}{$\begin{array}{c}\text { South } \\
\text { Africa } \\
\text { (Afro- } \\
\text { centric) } \\
\end{array}$} & \multirow{2}{*}{$\begin{array}{c}\begin{array}{c}\text { South } \\
\text { Africa } \\
\text { (Euro- } \\
\text { centric) }\end{array} \\
\end{array}$} \\
\hline \multirow{5}{*}{ Hofstede } & Power Distance & & & & & & \\
\hline & $\begin{array}{l}\text { Resistance to } \\
\text { Uncertainty }\end{array}$ & & & & & & \\
\hline & $\begin{array}{l}\text { Individualism and } \\
\text { Collectivism }\end{array}$ & & & & & & \\
\hline & $\begin{array}{l}\text { Masculinity and } \\
\text { Femininity }\end{array}$ & & & & & & \\
\hline & $\begin{array}{l}\text { Confucian } \\
\text { Dynamism }\end{array}$ & & & & & & \\
\hline
\end{tabular}


Table 9. Continued...

\begin{tabular}{|c|c|c|c|c|c|c|c|}
\hline \multicolumn{2}{|c|}{ Dimensions/Countries } & \multirow[t]{2}{*}{ Brazil } & \multirow[t]{2}{*}{ Russia } & \multirow[t]{2}{*}{ India } & \multirow[t]{2}{*}{ China } & \multirow{2}{*}{$\begin{array}{l}\text { South } \\
\text { Africa } \\
\text { (Afro- } \\
\text { centric) } \\
\end{array}$} & \multirow{2}{*}{$\begin{array}{l}\text { South } \\
\text { Africa } \\
\text { (Euro- } \\
\text { centric) }\end{array}$} \\
\hline \multirow{7}{*}{$\begin{array}{c}\text { Trompenaars } \\
\text { and } \\
\text { Hampden- } \\
\text { Turner }\end{array}$} & $\begin{array}{l}\text { Universalism- } \\
\text { Particularism }\end{array}$ & & & & & & \\
\hline & $\begin{array}{l}\text { Individualism- } \\
\text { Communitarianism }\end{array}$ & & & & & & \\
\hline & Specific-Diffuse & & & & & & \\
\hline & Neutral-Emotional & & & & & & \\
\hline & $\begin{array}{l}\text { Achievement- } \\
\text { Ascription }\end{array}$ & & & & & & \\
\hline & Time Perspective & & & & & & \\
\hline & $\begin{array}{l}\text { Relationship with } \\
\text { the environment }\end{array}$ & $\diamond$ & $\diamond$ & $\diamond$ & $\diamond$ & $\diamond$ & \\
\hline \multirow{3}{*}{ Hall } & Context & & & & & & \\
\hline & Space & & & & & & \\
\hline & Time & & & & & & \\
\hline \multirow{3}{*}{ Schwartz } & $\begin{array}{c}\text { Embeddedness- } \\
\text { Autonomy }\end{array}$ & & & & & & \\
\hline & $\begin{array}{l}\text { Hierarchy- } \\
\text { Egalitarianism }\end{array}$ & $\diamond$ & $\diamond$ & $\diamond$ & $\diamond$ & $\diamond$ & $\diamond$ \\
\hline & Mastery-Harmony & $\diamond$ & $\diamond$ & $\diamond$ & $\diamond$ & $\diamond$ & $\diamond$ \\
\hline \multirow{5}{*}{$\begin{array}{l}\text { Kluckhohn } \\
\text { and } \\
\text { Strodtbeck }\end{array}$} & $\begin{array}{l}\text { Relationship with } \\
\text { Nature }\end{array}$ & $\diamond$ & $\diamond$ & $\diamond$ & $\diamond$ & $\diamond$ & $\diamond$ \\
\hline & $\begin{array}{l}\text { Relationship with } \\
\text { People }\end{array}$ & & & & & & \\
\hline & Human Activities & & & & & & \\
\hline & $\begin{array}{c}\text { Relationship with } \\
\text { Time }\end{array}$ & & & & & & \\
\hline & Human Nature & $\diamond$ & $\diamond$ & $\diamond$ & $\diamond$ & $\diamond$ & $\diamond$ \\
\hline
\end{tabular}

Source: The authors themselves

Using the theory to analyse it, one can see that when comparing the ideal dimensions (Table 1) with the dimensions that they have in common, the BRICS countries are aligned to the discussion in this Table 1 only regarding those dimensions put forth by Kluckhohn and Strodtbeck, Relationship with Nature (harmony) and Human Nature (neutral). Despite the importance of these dimensions, this analysis reveals that the countries should heed the other dimensions if they are to improve their entrepreneurial expression, starting with those ideal dimensions that not even (Eurocentric) South Africa possesses. This Table shows why BRICS countries have low level of entrepreneurship (see their position in the GEI ranking - Table 2), and the differences among them (as we discussed in section 4.1). These differences are the results of their political and economic systems, geography, and cultural and ethics characteristics.

\section{CONCLUSION}

The BRICS hare risen to global prominence because of the growth of their local economies and geopolitical relevance. By associating the predominant cultural elements in each of these nations with the models of cultural dimensions explored in this article Hofstede, Trompenaars and Hampden-Turner, Hall, Schwartz, Kluckhohn and Strodtbeck - and by comparing each allocated dimension with those that are considered as ideal for entrepreneurship in a country, one can see that, in general, the countries analyzed here have 
cultural characteristics that are distant from the proposed ideal. This corroborates the analyses made available in the GEM and the result presented by the GEI 2018 study, which places the BRICS in intermediate positions in the global entrepreneurship ranking, based on the low score that these countries obtained in relation to the first placed countries. This result indicates a still poorly developed entrepreneurial culture in these locations. Within the nations analyzed here, China obtained the best placement in the ranking, although South Africa it is precisely the BRICS country with the cultural characteristics closest to those considered ideal for the existence of an entrepreneurial attitude in a country. Nevertheless, its score is still significantly lower than the more well-placed countries.

It is worth mentioning that the surveyed models have dimensions with underlying ideas that are addressed by more than one of them. Among these, we can highlight power distance and those dimensions that involve individualism versus collectivism, since the predominance of a great power distance tends to generate obstacles to innovation and entrepreneurship, and since individualist societies tend to be marked by autonomy in the way individuals act and think, contributing to the occurrence of entrepreneurial activities (Hayton et al., 2002; Lee and Peterson, 2000; Godói-de-Sousa et al., 2014). When analysing the models of cultural dimensions after applying them to each one of the BRICS countries, one can see that the two highlighted dimensions tend to manifest themselves in the most harmful way for the occurrence and the development of entrepreneurial activities, indicating the presence of still poorly developed entrepreneurial cultures in these nations. In addition, after analysing the dimensions that should stimulate entrepreneurial behaviour and crosschecking them with the dimensions of each country, only the dimensions of Kluckhohn and Strodtbeck (relationship with nature/harmony and human nature/neutral) were common to the countries.

One can therefore conclude that, besides the cultural elements of a country, economic aspects contribute to explain the entrepreneurial culture of a nation. When we compare China and South Africa (Table 2), we can see that China is the best positioned country in this group according to entrepreneurial country by Ács et al. (2018). This advantage is null when we compare it with South Africa in entrepreneurship by opportunity, mainly in male gender (Global Entrepreneurship Monitor, 2018), it is in a lower position (51th in 54 countries), comparing with South Africa ( $13^{\text {th }}$ in 54 countries). This conclusion corroborates the idea that entrepreneurial attitudes and maybe economic aspects are affected by the cultural traits of the nation to which it belongs, by the most influent productive sector in the economy, by prominent sectors, by the nature of the entrepreneurship (opportunity or necessity), and by the dimensions of the authors under study.

These results can guide the governments of these countries to apply other politics for education, science and technology, innovation, and patents (including property rights), integrating the education, research, science and funding sector, to provide the basis of a system which will lead these nations to a better progress. These initiatives demand a stronger participation of government - in the traditional triple helix - that can build the basis of an entrepreneurial system, investing their time and resources in production, finance, legal, and political aspects in these economies.

The limitations of this research are the context that it was developed (after a class about entrepreneurship), which made it less deep than the theme requires, the data that is spread in different kinds of bibliographic materials (books, papers, reports, websites, and so on), and the speed of changings in global economy.

There are many possibilities to develop future research, such as upgrade the literature review, searching for new papers about the countries and the subject, putting them together and making new analysis; write the same kind of analysis, but in different set of countries; focusing on innovation, incubators and their relationship with entrepreneurship in BRICS countries. So, this paper is just the beginning of a journey about this theme.

\section{REFERENCES}

Ács, Z.J., Szerb, L. and Lloyd, A. (2018), The Global Entrepreneurship Index. The Global Entrepreneurship and Development Institute, Washington, D.C., USA, pp. 1-43, available at: https://thegedi.org/wpcontent/uploads/2017/11/2018-front-cover-01.png (accessed 12 April 2019). 
Ahlstrom, D. and Bruton, G. (2009), International Management: Strategy and Culture in the Emerging World, 1 st ed., South-Western College Pub, Boston.

Ardichvili, A., Jondle, D., Kowske, B. et al. (2012), “Ethical cultures in large business organizations in Brazil, Russia, India, and China", Journal of Business Ethics, Vol. 105, pp. 415-428. https://doi.org/10.1007/s10551-011-0976-9.

Bansal, C.L. and Aggarwal, S. (2017), "Public policy paradox in enforcement of Foreign Arbitral Awards in BRICS countries: a comparative analysis of legislative and judicial approach", International Journal of Law and Management, Vol. 59, No. 6, pp. 1279-91. https://doi.org/10.1108/IJLMA-09-2016-0079.

BBC (2015). "Novo método para classificação de países acaba com conceito de 'emergentes"', available at: http://www.bbc.com/portuguese/noticias/2015/08/150814_economia_paises_hb (accessed 12 September 2015).

Bertsch, A. and Ondracek, J. (2010), "The risks and rewards of doing business in Brazil: can Brazil escape the fate of Greece", Mountain Plains Journal of Business and Economics, Vol. 11, pp. 23-42.

Brasil. (2019), “BRICS: Brazil, Russia, India, China, South Africa”. Ministry of Foreign Affairs, available at: http://www.itamaraty.gov.br/en/politica-externa/mecanismos-inter-regionais/7505-brics-brazilrussia-india-china-south-africa (accessed 11 January 2019).

Bremmer, I. (2017), "The Mixed Fortunes of the BRICS Countries, in 5 Facts: World Risk Report". Time, available at: http://time.com/4923837/brics-summit-xiamen-mixed-fortunes (accessed 12 November 2018).

Cao, Z. and Zhou, M. (2018), "Research on the innovation and entrepreneurship education mode in colleges and universities based on entrepreneurial ecosystem theory", Kuram ve Uygulamada Egitim Bilimleri, Vol. 18, No. 5, pp. 1612-9.

Chan, A.M. and Rossiter, J.R. (1998), "Construction of a chineseness values scale and a chineseness ethnicity scale", Asia Pacific Advances in Consumer Research, Vol. 3, pp. 61-7.

Chan, S. (1999), "The Chinese Learner: a question of style", Education + Training, Vol. 41, pp. 6-17.

Chatterjee, S.R. and Heuer, M. (2006), "Understanding Indian management in a time of transition”, in Davis, H. J., Chatterjee, S. R. and Heuer, M. (Eds.), Management in India: Trends and Transition, 1st ed., Sage Publications Inc., London, pp. 11-27.

Chevrier, S., Brannen, M.Y. and Hansen, C. (2014), “Uses and benefits of qualitative approaches to culture in intercultural collaboration research", in 5th ACM International Conference on Collaboration Across Boundaries: Culture, Distance and Technology, Kyoto, Japão.

Chima, O. (2013), "Sanusi: China is major contributor to Africa's de-industrialisation". This Day, All Africa, 13 March, available at: https://allafrica.com/stories/201303130168.html (accessed 25 April 2019).

De Beer, J. (1997), South African Myers-Briggs type contribution: a comparative study, Tese de Doutorado em Artes, Rand Afrikaans University, Auckland Park, Johannesburg.

Dreher, M.T. (2004), Empreendedorismo e Responsabilidade Ambiental: uma Abordagem de Empreendimentos Turísticos, Tese de Doutorado em Engenharia de Produção, Universidade Federal de Santa Catarina, Florianópolis, SC.

Faust, M., Schneider, F., Herdin, T. et al. (2018), "BRICS as formation to study visual online communication? A dialogue on historical origins, perspectives on theory and future directions", China Media Research, Vol. 14, No. 2, pp. 85-97.

Fernandes, M.F.G. (2008), Negociação Brasil e China: seus principais aspectos culturais, Dissertação de Mestrado em Gestão Empresarial, Fundação Getúlio Vargas, Rio de Janeiro, RJ.

Fontenele, R.E.S., Sousa, P.F.B. and Lima, A.O. (2011), “Empreendedorismo, crescimento econômico e competividade dos BRICS: uma análise empírica a partir dos dados do GEM e GCI", in XXXV ENANPAD: Encontro Nacional da Pós Graduação e Pesquisa em Administração, Rio de Janeiro, RJ.

Gelfand, M.J. and Brett, J.M. (2004). "Integrating negotiation and culture research", in Gelfand, M.J., Brett, J.M. (Eds.), The Handbook of Negotiation and Culture, 1st ed., Stanford University Press, Stanford.

Gilbert, K. (2001), "In Search of Russian culture: the interplay of organizational, environmental and cultural factors in Russian-Western partnerships", Working Paper Series, pp. 1-21.

Global Entrepreneurship Monitor - GEM (2018), Global Report 2017-2018, Global Entrepreneurship Research Association (GERA), pp. 1-154.

Godói-de-Sousa, E., Bueno, J.M., Sousa, M.G. et al. (2014), "O Perfil do Empreendedor Social e suas Dimensões de Atuação: seis casos no município de Uberlândia", Revista Interdisciplinar de Gestão Social, Vol. 3, No. 1, pp. 33-56. 
Gonzalez, A.L., Jaen, I., Topa, G. et al. (2019), "University environment and entrepreneurial intention: the mediating role of the components of the theory of planned behaviour", Revista de Psicología Social, Vol. 34, No. 1, pp. 137-67. http://dx.doi.org/10.1080/02134748.2018.1542789.

Grachev, M.V. and Bobina, M.A. (2006), "Russian Organizational Leadership: lessons from the Globe Study", International Journal of Leadership Studies, Vol. 1, No. 2, pp. 67-79.

Hall, E.T. and Hall, M.R. (1990), Understanding Cultural Differences: Germans, French and Americans, 1st ed., Intercultural Press, Yarmouth.

Hasan, M.D.A. (2016), FDI Inflows in BRICS Nations and Impact of FDI in Development of BRICS, Dissertação de Mestrado em Gestão de Negócios Internacionais, School of Business and Law, University of East London, London, England.

Hayton, J., George, G. and Zahra, S. (2002), "National culture and entrepreneurship: a review of behavioral research", Entrepreneurship Theory and Practice, Vol. 26, No. 4, pp. 33-52.

Heuer, M. (2006), "The influence of Indian national culture on organizations", in Davis, H.J., Chatterjee, S.R., Heuer, M. (Eds.), Management in India: Trends and Transition, 1st ed., Sage Publications Inc., London, pp. 28-48.

Hofstede, G. (2015a), "What about Brazil?", available at: https://www.hofstede-insights.com/countrycomparison/brazil/ (accessed 12 November 2018).

Hofstede, G. (2015b), "What about Russia?", available at: https://www.hofstede-insights.com/countrycomparison/russia/ (accessed 12 November 2018).

Hofstede, G. (2015c), "What about India?", available at: https://www.hofstede-insights.com/countrycomparison/india/ (accessed 12 November 2018).

Hofstede, G. (2015d), "What about China?", available at: https://www.hofstedeinsights.com/country/china/ (accessed 12 November 2018).

Hofstede, G., Hofstede, G.J. and Minkov, M. (2001), Cultures and Organizations: Software of the Mind, 1st ed., McGraw-Hill, New York.

lacob, D. and Dumitrescu, V.M. (2012), "Cultural awareness, sensitivity and competence: basic requirements for business success in Nepal and South Africa", Synergy Bucharest, Vol. 8, No. 2, pp. 121-34.

International Monetary Fund - IMF (2013), "World economic outlook database", available at: http://www.imf.org/external/pubs/ft/weo/2013/01/weodata/weorept.aspx?pr.x=91 andpr.y=5andsy $=2011$ andey $=2018$ andscsm $=1$ andssd $=1$ andsort $=$ countryandds $=$.andbr $=1$ and $=223 \% 2$ C924\%2C922 \%2C199\%2C534ands=NGDPD\%2CNGDPDPC\%2CPPPGDP\%2CPPPPCandgrp=0anda= (accessed 12 November 2018).

Khan, A. and Farooquie, J. (2016), "Motives and benefits of ISO 9001 Quality Management System: an empirical study of Indian SMEs", Brazilian Journal of Operations \& Production Management, Vol. 13, No. 3, pp. 320-9. https://doi.org/https://doi.org/10.14488/BJOPM.2016.v13.n3.a8

Kluckhohn, F.R. and Strodtbeck, F.L. (1961), Variations in Value Orientations, 1st ed., Row Peterson, Evanston.

Lacerda, D.P. (2011), "Cultura organizacional: sinergias e alergias entre Hofstede e Trompenaars", Revista de Administração Pública, Vol. 45, No. 5, pp. 1285-301.

Lee, S.M. and Peterson, S.J. (2000), "Culture, entrepreneurial orientation, and global competitiveness", Journal of World Business, Vol. 35, No. 4, pp. 401-16.

Lewis, R.D. (1999), When Cultures Collide: Managing Successfully Across Cultures, 1st ed., Nicholas Brealey, London.

Leydesdorff, L.; Etzkowitz, H. (1996), “Emergence of a Triple Helix of university-industry-government relations", Science and Public Policy, Vol. 23, No. 5, pp. 279-86.

Lund-Thomsen, P. and Wad, P. (2014), "Global value chains, local economic organization and corporate social responsibility in the BRICS countries", Competition \& Change, Vol. 18, No. 4, pp. 281-90.

Lynn, M. and Gelb, B.D. (1996), "Identifying innovative national markets for technical consumer goods", International Marketing Review, Vol. 13, No. 6, pp. 43-57.

Massarova, A. and Potapenko, M. (2018), "Approaches to poverty measurement in BRICS: a reflection on economic reality: the case of Brazil, China and Russia", Bulletin of Geography. Socio-Economic Series, Vol. 42, No. 42, pp. 183-94.

McCarthy, D.J., Puffer, S.M. and Darda, S.V. (2010), "Convergence in Entrepreneurial Leadership Style: evidence from Russia", California Management Review, Vol. 52, No. 4, pp. 48-72. 
Nardon, L. and Steers, R.M. (2009), The Culture Theory Jungle: Divergence and Convergence in Models of National Culture, 1st ed., Cambridge University Press, Cambridge.

Nishimura, S., Nevgi, A., Tella, S. (2008), “Communication style and cultural features in high/low context communication cultures: a case study of Finland, Japan and India", in Ainedidaktiikan Symposiumi, Helsinki.

Oliveira, M. M. (2007), Como Fazer Pesquisa Qualitativa, Vozes, Petrópolis.

Overgaard, L. (2010), An Analysis of Indian Culture in an Era of Globalisation, Dissertação de Mestrado em Administração e Gestão de Comunicação, Aarhus University, Aarhus, Denmark.

Pearson, S. and Leahy, J. (2011), "Cheap Asia imports hit Brazil's industries" Financial Times, 20 April, available at: https://www.ft.com/content/e7206ccc-6b71-11e0-a53e-00144feab49a (accessed 25 April 2019).

Ratten, V. (2014), "Future research directions for collective entrepreneurship in developing countries: a small and medium-sized enterprise perspective", International Journal of Entrepreneurship and Small Business, Vol. 22, No. 2, pp. 266-74.

Schmidt, C.M. and Dreher, M.T. (2008), "Cultura empreendedora: empreendedorismo coletivo e perfil empreendedor", Revista de Gestão USP, Vol. 15, No. 1, pp. 1-14.

Schwartz, S.H. (2012), "An overview of the Schwartz theory of basic values", Online Readings in Psychology and Culture, Vol. 2, No. 1, pp. 1-20.

Shane, S. (1993), "Cultural influences on national rates of innovation", Journal of Business Venturing, Vol. 8, pp. 59-73.

Smit, P.J., Brevis, T., Cronje, G.J., De, J. and Vrba, M.J. (2004), Management Principles: a Contemporary Edition for Africa. 3rd ed. Juta Academic, Claremont.

Steers, R.M. and Nardon, L. (2005), Managing in the Global Economy, 2nd ed., M.E. Sharpe, New York.

Stevenson, H.H. and Gumpert, D.E. (1985), "The heart of entrepreneurship", Harvard Business Review, Vol. 1, No. 63, pp. 85-94.

Thakur, R. (2014), "How representative are BRICS", Third World Quarterly, Vol. 35, No. 10, pp. 1791-808. http://dx.doi.org/10.1080/01436597.2014.971594.

Thampi, P.P., Jyotishi, A. and Bishu, R. (2015), "Cultural characteristics of small business entrepreneurs in India: examining the adequacy of Hofstede's framework", International Journal of Business and Globalisation, Vol. 15, No. 4, pp. 475-95.

Thomas, D.C. and Peterson, M.F. (2014), Cross-Cultural Concepts: Essential Concepts, 3rd ed., Sage Publications, London.

Trompenaars, F. and Hampden-Turner, C. (1997), Riding the Waves of Culture: Understanding Diversity in Global Business, 1st ed., Nicholas Brealey Publishing, London.

Van Everdingen, Y.M. and Waarts, E. (2003), "The effect of national culture on the adoption of innovations", Marketing Letters, Vol. 14, No. 3, pp. 217-32.

Yi, S. and Duval-Couetil, N. (2018), "What drives engineering students to be entrepreneurs? Evidence of validity for an entrepreneurial motivation scale", Journal of Engineering Education, Vol. 107, No. 2, pp. 291-317. http://dx.doi.org/10.1002/jee.20199.

Author contributions: The authors' contributions are equal. 